\title{
Goldmann 視野計による複視の測定
}

\author{
近江眼科 井川千家子・川口薰・壸井登柴子
}

藤田＼cjkstart純子・森本 貴子・中川登紀子

元来，複視を訴元来院する患者に対し， red green test, Hess chart, Synoptophore, 黒 板複視計などの各種検查を総合して，診断を下 していた。てれらはいずれも複視を質的に捉元
は検出できない欠点がある，すなわち回旋複視 の測定ができない。（2)交叉性か同側性か，等 その他質的な測定は别に行なう必要があり, て れはあくまで補助的手段である。
るもので, 我々がてのたび試み た Goldmann 視野計による測定 は，複視を量的に捉えようとす るものである。

測定手技

指標および背影照度を，通常 の視野と同様にセットしてお き, 両眼開放で頭部を正しく固 定し，中心を目の中心部にあわ せる。次詣標を目で追わせ て, 複視の範囲を測定する。我 々はてれを複視野と名つけけた。

測定結果の例

眼筋麻疸患者の複視野の幾つ か(第 1，2図)を示しておく。 ての測定の特長

利点としては，（1)簡単に測 れる，(2)いままで質的に測ら れていた複視を，あるていど量 的に示せる。てれは，とくに眼 筋麻㾝などの病状経過を追うの 亿役立つと思われる。 (3) 従来 の検査は，正面上り各方向 30 度 位までの範囲での複視を調べて いたが，眼球運動の範团一ぱい まで，すなわち注視野の一極の 範囲まで，複視を測定するてと ができる。

また視標の大きさ，明るさを 変えて融像との関係をみること も考えている。てれらの長所に 対し欠点としては，(1)ての方 法は，麻痺などによる眼球回㳬

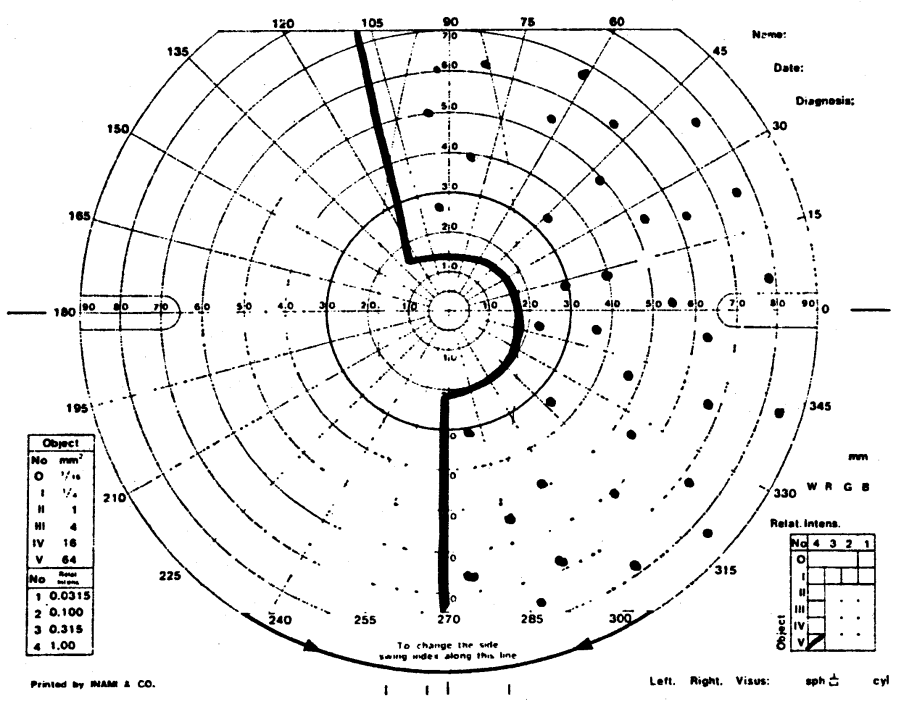

第 1 図 左眼内直筋麻疸 点々は，三つに見える範囲を示す。

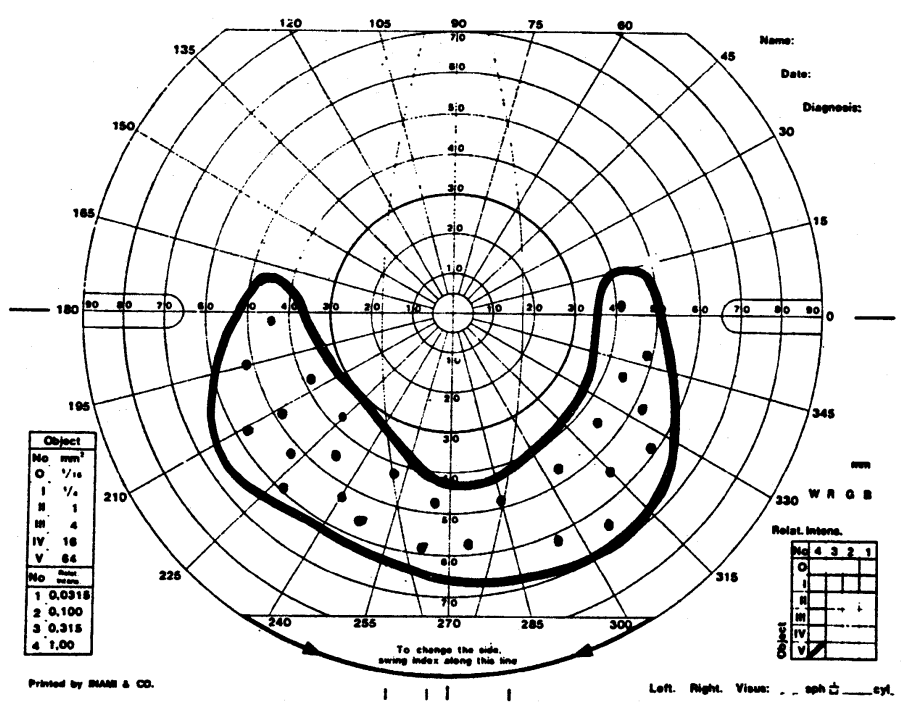

第 2 図 右眼上斜笳麻瘏左眼内直笳麻瘏の疑い 点々は, 二つに 見える範囲を示す。 